\title{
Effect of Pre-Treatments on Quality Attributes of Solar Dehydrated Grape Pomace
}

\author{
P. Mamatha ${ }^{1 *}$, K. Vanajalatha ${ }^{1}$, Veena Joshi ${ }^{1}$ and S. Narender Reddy ${ }^{2}$ \\ ${ }^{1}$ Department of Fruit Science, College of Horticulture, SKLTSHU, \\ Rajendranagar, Telangana, India \\ ${ }^{2}$ Deparment of crop physiology, College of Agriculture, PJTSAU, \\ Rajendranagar, Telangana, India \\ *Corresponding author
}

\begin{tabular}{|c|c|}
\hline & A B S T R A C T \\
\hline & \multirow{7}{*}{$\begin{array}{l}\text { The focus of this research was to analyze the physico-chemical and nutritional quality of a } \\
\text { solar dried grape pomace as affected by eight chemical pre-treatments. Based on } \\
\text { preliminary tests, grape pomace was dipped in } 1 \%(\mathrm{w} / \mathrm{v}) \text { Calcium chloride }\left(\mathrm{T}_{1}\right), 1 \%(\mathrm{w} / \mathrm{v}) \\
\text { Citric acid }\left(\mathrm{T}_{2}\right), 1 \%(\mathrm{w} / \mathrm{v}) \text { Potassium metabisulphite }\left(\mathrm{T}_{3}\right), 2 \%(\mathrm{w} / \mathrm{v}) \text { Sodium chloride }\left(\mathrm{T}_{4}\right) \\
\text { independently and } 1 \%(\mathrm{w} / \mathrm{v}) \text { Citric acid along with } 0.5 \%(\mathrm{w} / \mathrm{v}) \text { potassium metabisulphite } \\
\left(\mathrm{T}_{5}\right), 1 \%(\mathrm{w} / \mathrm{v}) \text { Calcium chloride along with } 0.5 \%(\mathrm{w} / \mathrm{v}) \text { citric acid }\left(\mathrm{T}_{6}\right) \text { and } 1 \%(\mathrm{w} / \mathrm{v}) \\
\text { Potassium metabisulphite along with } 1 \%(\mathrm{w} / \mathrm{v}) \text { calcium chloride }\left(\mathrm{T}_{7}\right) \text {, and in water solution } \\
\left(\mathrm{T}_{8}\right) \text { for } 5 \text { minutes. Quality characteristics of dehydrated grape pomace viz. moisture } \\
\text { content, Tss, sugars, titratable acidity, total polyphenol and anthocyanins content, recovery } \\
\% \text {, dehydration ratio, rehydration and reconstitutability ratio as affected by pretreatment } \\
\text { process were studied. The results expressed that the dehydrated grape pomace pre-treated } \\
\text { with } 1 \% \text { (w/v) Potassium metabisulphite along with } 1 \%(\mathrm{w} / \mathrm{v}) \text { calcium chloride }\left(\mathrm{T}_{7}\right) \text { had } \\
\text { recorded highest recovery per cent }(26.32) \text {, rehydration ratio }(1.57) \text {, reconstitutability ratio } \\
(0.41) \text {, TSS }\left(8.69^{\circ} \mathrm{B}\right) \text {, reducing sugars }(12.84 \%) \text {, total sugars }(16.63 \%) \text {, minimum acidity } \\
(0.66 \%) \text { and lowest dehydration ratio }(3.79) \text {, with preferred moisture content }(5.60 \%) \\
\text { followed by } 1 \%(\mathrm{w} / \mathrm{v}) \text { Citric acid along with } 0.5 \%(\mathrm{w} / \mathrm{v}) \text { potassium metabisulphite }\left(\mathrm{T}_{5}\right) \text { ). } \\
\text { Higher content of total polyphenols }(17.21 \mathrm{mg} / 100 \mathrm{~g}) \text { and anthocyanins }(62.08 \mathrm{mg} / 100 \mathrm{~g}) \\
\text { were recorded in } 1 \% \text { (w/v) Citric acid along with } 0.5 \%(\mathrm{w} / \mathrm{v}) \text { potassium metabisulphite } \\
\left(\mathrm{T}_{5}\right) \text {. }\end{array}$} \\
\hline Keywords & \\
\hline & \\
\hline $\begin{array}{l}\text { Polyphenols. Solar } \\
\text { drying. } \\
\text { Anthocyanins. }\end{array}$ & \\
\hline Article Info & \\
\hline $\begin{array}{l}\text { Accepted: } \\
29 \text { May } 2017 \\
\text { Available Online: } \\
\text { 10 June } 2017\end{array}$ & \\
\hline & \\
\hline
\end{tabular}

\section{Introduction}

Grape (Vitis vinifera L), basically temperate crop which has got adapted to sub-tropical climate of peninsular India belongs to the family Vitaceae and one of the most important commercial fruit crops of India. In India, Grape occupies 1.6\% of total fruit area, $2.9 \%$ of total fruit production and grown in an area of 118.7 thousand hectares with a total production of 2585.3 thousand MT and productivity of $21.8 \mathrm{MT} / \mathrm{ha}$ (NHB 2015-16 data base). In India, Maharashtra is the leading state in grape production and Telangana accounts for only 1 per cent of total production.

Grape is rich source of phenolic and fiber compounds and intake of grape products such as juice or wine have recognized health 
benefits (Xia et al., 2010). About $80 \%$ of the world production is utilized for wine making, $10 \%$ for table purpose and the balance $10 \%$ for raisin and juice purpose.

Among grape processing industries, the wine industry produces million tons of left-over followed by juice industries that represent an ecological and economical waste management issue. About $20 \%$ of the weight of processed grapes remains as grape pomace (Pomace is the general term for any solid material such as the skins, pulp and seeds leftover after wine or juice extraction). Unlike grape flesh, grape skin and seeds are the potential source of antioxidant and anticarcinogenic phenolic compounds (Cantos et al., 2002) and also contains concentrated pro-anthocyanidins, carotenoids, xanthophylls, anthocyanins, tannins etc.

Recovery of phenols and fibre from grape pomace has attracted increasing attention in the past years, and industries are finding high value and sustainable alternative to the residues. Grape pomace is a potential source of phytochemicals that may be recovered as functional compounds for the pharmaceutical, cosmetic, food industries and as biopesticides (Fontana et al., 2013). It is also known that polyphenols have health-promoting effects and anti-aging properties there by prevent risk factors related to metabolic syndrome and several chronic diseases in aging humans (Galleano et al., 2012). These biological properties of polyphenols are attributed mainly to their powerful antioxidant and antiradical activities.

Grape pomace utilization for food industrial application has not been fully exploited due to short storage life resulted from its microbial spoilage, instability of anthocyanins during storage, difficulty in bulk handling and lack of knowledge on improved methods of storage (Mahajan et al., 2009). In addition to finding, a productive use for a waste product and market demand for natural antioxidants rather than chemical antioxidants has directly increased the demand for novel polyphenolic and fibre containing ingredients, but the information regarding simple technologies for drying/dehydration of this waste (pomace) that can be adopted for small farmers at field level is lacking. So far reported research findings on the efficiency of pre-treatments on quality attributes and storage of grape pomace are very limited. Therefore present study was undertaken to develop simple pretreatments for dehydration and storage of grape pomace.

Keeping in view the above points the present study on effect of pre-treatments on quality attributes of grape pomace is proposed with the following objective: To study the effect of different pre-treatments on the quality of solar dehydrated grape pomace.

\section{Materials and Methods}

\section{Preparation of dehydrated grape pomace}

Fully matured fresh blue grape berries of Bangalore Blue variety were procured from the local market of Hyderabad, India. The fruits were then sorted and graded for uniform maturity, color and size.

These graded grapes were then washed thoroughly with tap water. The cleaned grapes were destalked, loaded into the fruit pulper equipment and the juice was separated, the grape pomace thus obtained were pretreated (plate 1) based on preliminary tests before dehydration as follows: a)

Dipping in $1 \mathrm{~g} / 100 \mathrm{ml} \mathrm{CaCl}_{2}$ in water solution for 5 min. b) Dipping in Potassium Metabisulphite (KMS) $1 \mathrm{~g} / 100 \mathrm{ml}$ solution for 5 min. c) Dipping in $1 \mathrm{~g} / 100 \mathrm{ml} \mathrm{CaCl}_{2}$ in combination with $1 \mathrm{~g} / 100 \mathrm{ml} \mathrm{KMS}$ for $5 \mathrm{~min}$. 
d) Dipping in $2 \mathrm{~g} / 100 \mathrm{ml} \mathrm{NaCl}$ for 5 min. e) Grape pomace dipped in plain water for $5 \mathrm{~min}$ at room temperature were considered as control sample. The pretreated and dehydrated grape pomace thus obtained was analyzed for physico chemical and nutritional quality.

\section{Solar powered Air dryer (SDM - 50)}

The solar dryer has a metal cabinet made of aluminum alloy, (anti corrosive material) with a glass window on the top. The cabinet is provided with trays inside for placing the material to be dried \& the cabinet is modular in nature.

The solar radiation passes through the transparent glass window, located on the top of the cabinet, which is oriented to South direction with a tilt equal to latitude $20^{\circ}$ to collect maximum solar radiation

\section{Chemical analysis}

The fresh and dehydrated grape pomace were analyzed for moisture per cent, TSS, total sugars, reducing sugars, titratable acidity, recovery per cent, dehydration ratio, rehydration ratio and reconstitutability ratio by using standard methods (Ranganna 1998). All chemical characteristics were analyzed in triplicate.

\section{Total polyphenols}

The samples were measured by colorimetric method by Folin-ciocalteau reagent at $765 \mathrm{~nm}$ using UV visible spectrophometer Singleton et al., (1999).

\section{Total anthocyanins}

The samples were determined by colorimetric method suggested by Srivastava and Kumar (2002) at $535 \mathrm{~nm}$ using UV visible spectrophotometer and expressed in $\mathrm{mg}$ of anthocyanins/100 $\mathrm{g}$ of fresh weight.

\section{Statistical analysis}

The data for various physico-chemical attributes were analyzed by using completely randomized design (CRD) according to Mahony (1985).

\section{Results and Discussion}

Some of chemical and physical properties of fresh grape and fresh grape pomace are shown in table 1 . The highest recovery of dried pomace was $26.32 \%$ in $\mathrm{T}_{7}$ whereas in control $\mathrm{T}_{8}$ it was $11.05 \%$ (Table 2), which may be due to losses of solids during pretreatments. The results of present investigation are in accordance with the findings of mozumder $e t$ al., (2012) in dehydrated tomato.

\section{Dehydration ratio}

Significant difference was observed among the treatments it is evident from table 2. The highest dehydration ratio of 9.04 was recorded in $\mathrm{T}_{8}$ (control) and the lowest dehydration ratio of 3.79 recorded in $T_{7}$, increased water removal and moisture mobility in pomace during drying influenced the drying kinetics of pomace. Similar observations were reported by mozumder et $a l$. , (2012) in dehydrated tomato.

\section{Rehydration ratio}

Rehydration is considered as a measure of the injury to the material caused by drying and treatment preceding dehydration and is the phenomenon that decides the effectiveness of the final product. The data is evident from table 2. The results showed that there was significant difference among the treatments. Highest rehydration ratio of 1.57 was recorded in $T_{7}$ which was on par with $T_{5}$ recorded 1.55. The lowest value of 1.11 was recorded in $\mathrm{T}_{8}$ (control).

Combination of $\mathrm{CaCl}_{2}$ with $\mathrm{KMS}$ resulted in 
best rehydration properties and showed a higher value. The effectiveness of KMS on textural quality of pomace, and formation of open structure due to $\mathrm{CaCl}_{2}$ pretreatment concluded to better rehydration property and reconstitution of the product (Ghavidel and Davoodi, 2009).

\section{Reconstitutability ratio}

Significant difference was observed among the treatments (Table 2). Highest reconstitutability ratio of 0.41 was recorded in $\mathrm{T}_{7}$. The lowest value of 0.12 was recorded in $\mathrm{T}_{8}$ (control). Reconstitutability ratio refers to the recovery and quality of the dehydrated product in a single parameter. These results were similar to findings of Pruthi et al., (1978) in pretreated mushroom, and in dehydrated tomato by Ghavidel and Davoodi. (2009).

\section{Moisture content}

The final moisture content was reduced to below $10 \%$ for all pretreated samples with until no further changes in mass were observed. The data pertaining to the moisture content of the dehydrated pomace as influenced by pre-treatments are presented in table 3. The results showed that there was significant difference among the treatments. Lowest moisture content of 5.60 per cent was recorded in $\mathrm{T}_{7}$. The highest moisture of 7.10 per cent was recorded in $\mathrm{T}_{8}$. Among the treatments, Control $\left(\mathrm{T}_{8}\right)$ showed higher final moisture content. The results of present investigation are in accordance with the findings of Ghavidel and Davoodi (2009) and Mozumder et al., (2012) in dehydrated tomato. The moisture content is a governing factor for keeping quality of the product, which is influenced by pre-treatments. Results showed that pretreatment with KMS and $\mathrm{CaCl}_{2}$ increased water removal and moisture mobility in grape pomace during drying and these pretreatments influenced the drying kinetics of pomace by evident changes in texture.

\section{Total soluble solids}

The data pertaining to Total soluble solids content of the dehydrated grape pomace as influenced by pre-treatments are presented in table 3. After dehydration there was increase in TSS of all treatments when compared to fresh pomace. Loss of moisture and concentration effect resulted in increase in TSS of dried product (Abrol et al., 2014). The results showed that there was significant difference among the treatments. Highest TSS of $8.69^{\circ} \mathrm{B}$ was recorded in $\mathrm{T}_{7}$. The lowest TSS of $8.17^{\circ} \mathrm{B}$ was recorded in $\mathrm{T}_{8}$. The results of present investigation are in accordance with the findings of Patil et al., (2014) in pretreated jack fruit chips.

\section{Titrable acidity}

The results showed that there was significant difference among treatments table 3. Highest acidity of 0.90 per cent was recorded in $\mathrm{T}_{4}$. The lowest acidity of 0.64 per cent was recorded in $\mathrm{T}_{1}$.

Higher acidity in dried samples may be related to the partial fermentation occurred in some trials, due to longer time consumption and pectic enzyme activity in first hours of the process. Further the increase in acidity might be due to formation of acids because of inter-conversion of sugars and other chemical reactions. The results of present investigation are in accordance with the findings of Ghavidel and Davoodi (2009) in dehydrated tomato powder.

\section{Reducing sugars}

Highest reducing sugars of 12.84 per cent was recorded in $\mathrm{T}_{7}$. The lowest value of 10.44 per cent was recorded in $\mathrm{T}_{8}$ (control). After dehydration there was increase in reducing 
sugar content of all the treatments table 3, when compared to fresh pomace. The increase in the reducing sugar content might be due to the concentration of grape pomace during drying process. Similar increase in reducing sugars was observed in different fruits by Gallali et al., (2000) and Gajanana et al., (2010).

Plate.1 Flow chart for preparation of dehydrated grape pomace

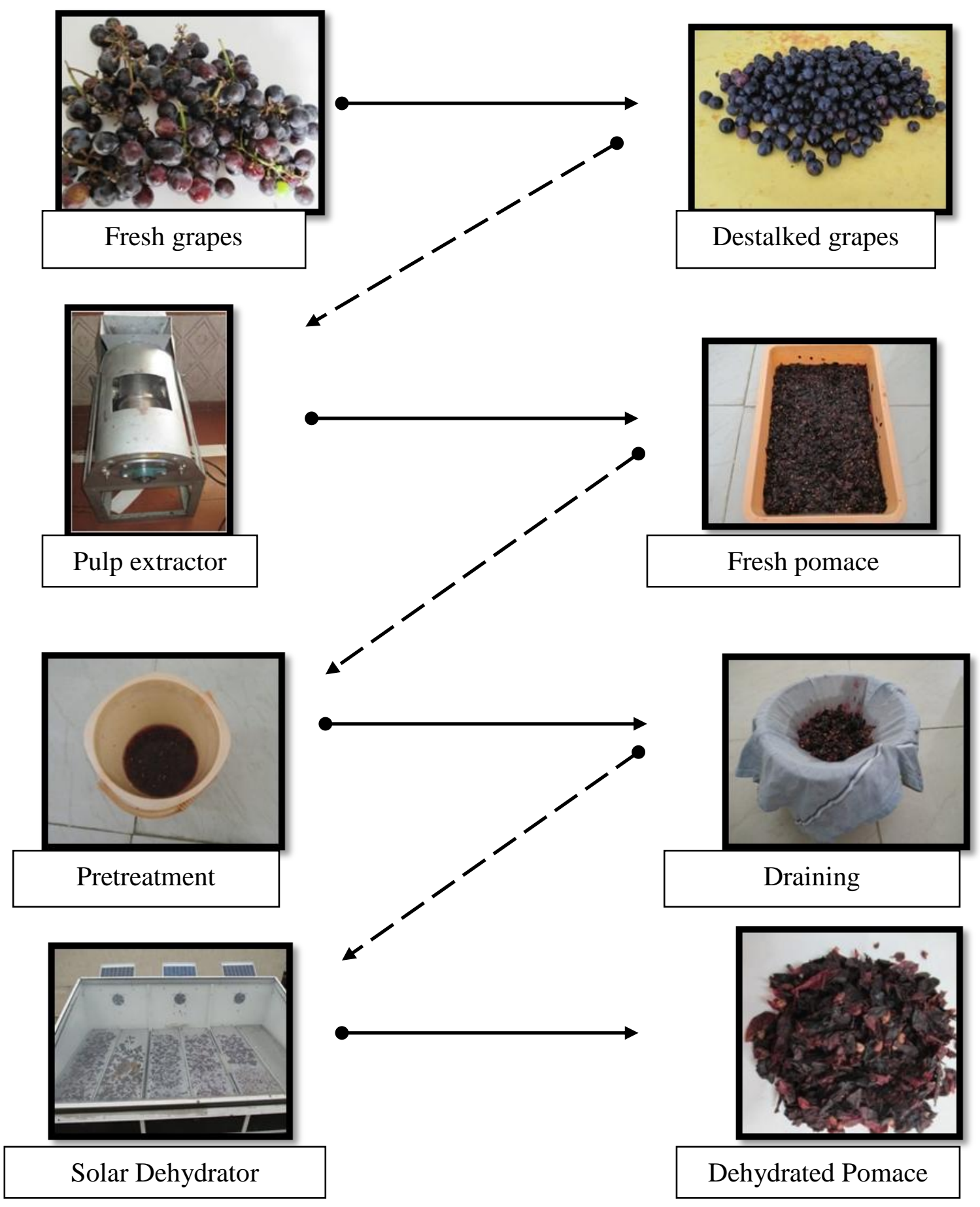


Table.1 Physico-chemical characteristics of fresh grape and fresh pomace var. 'Bangalore blue'

\begin{tabular}{|c|c|c|}
\hline Parameters & Fresh grape & Fresh grape pomace \\
\hline Moisture content (\%) & 80.52 & 71.35 \\
\hline TSS ( ${ }^{\circ}$ Brix) & 19.80 & 8.12 \\
\hline Acidity (\%) & 0.86 & 0.60 \\
\hline Reducing sugars (\%) & 13.93 & 10.34 \\
\hline Total sugars (\%) & 17.52 & 13.56 \\
\hline Total polyphenols (mg/100g) & 14.80 & 15.13 \\
\hline Anthocyanins (mg/100g) & 65.32 & 67.16 \\
\hline
\end{tabular}

Table.2 Effect of pre-treatments on Recovery (\%), dehydration ratio, rehydration ratio and reconstituability ratio of dehydrated grape pomace

\begin{tabular}{|c|c|c|c|c|c|}
\hline \multicolumn{2}{|c|}{ Treatment } & \multirow{2}{*}{$\begin{array}{c}\begin{array}{c}\text { Recovery } \\
(\%)\end{array} \\
13.60\end{array}$} & \multirow{2}{*}{$\begin{array}{c}\begin{array}{c}\text { Dehydration } \\
\text { ratio }\end{array} \\
7.35\end{array}$} & \multirow{2}{*}{$\begin{array}{c}\text { Rehydration } \\
\text { ratio }\end{array}$} & \multirow{2}{*}{$\begin{array}{c}\begin{array}{c}\text { Reconstituability } \\
\text { ratio }\end{array} \\
0.20\end{array}$} \\
\hline $\mathbf{T}_{1}$ & $\mathrm{CaCl}_{2} \mathbf{1 \%}$ & & & & \\
\hline $\mathbf{T}_{2}$ & CA $1 \%$ & 12.52 & 7.98 & 1.43 & 0.17 \\
\hline $\mathbf{T}_{3}$ & KMS 1\% & 13.45 & 7.43 & 1.45 & 0.19 \\
\hline $\mathbf{T}_{4}$ & $\mathrm{NaCl} 2 \%$ & 11.34 & 8.81 & 1.16 & 0.13 \\
\hline $\mathbf{T}_{5}$ & CA $1 \%$ + KMS 0.5\% & 26.24 & 3.81 & 1.55 & 0.40 \\
\hline $\mathbf{T}_{6}$ & $\mathrm{CaCl}_{2} 1 \%+\mathrm{CA} 0.5 \%$ & 13.26 & 7.48 & 1.47 & 0.19 \\
\hline $\mathbf{T}_{7}$ & $\mathrm{KMS} 1 \%+\mathrm{CaCl}_{2} 1 \%$ & 26.32 & 3.79 & 1.57 & 0.41 \\
\hline $\mathbf{T}_{8}$ & Control & 11.05 & 9.04 & 1.11 & 0.12 \\
\hline \multicolumn{2}{|c|}{ S.E m \pm} & 0.06 & 0.02 & 0.01 & 0.006 \\
\hline \multicolumn{2}{|c|}{ C.D. at 5\% } & 0.19 & 0.07 & 0.04 & 0.017 \\
\hline
\end{tabular}

Table.3 Effect of pre-treatments on moisture content (\%), TSS ( ${ }^{\circ}$ Brix), acidity $(\%)$, reducing sugars (\%), total sugars (\%), total polyphenols (mg/100g) and Anthocyanins (mg/100g) of dehydrated grape pomace

\begin{tabular}{|c|c|c|c|c|c|c|c|c|}
\hline \multicolumn{2}{|c|}{ Treatment } & \multirow{2}{*}{$\begin{array}{c}\begin{array}{c}\text { Moisture } \\
(\%)\end{array} \\
6.13\end{array}$} & \multirow{2}{*}{$\begin{array}{c}\begin{array}{c}\text { TSS } \\
\left({ }^{\circ} \text { Brix }\right)\end{array} \\
8.37\end{array}$} & \multirow{2}{*}{$\begin{array}{c}\begin{array}{c}\text { Acidity } \\
(\%)\end{array} \\
0.64\end{array}$} & \multirow{2}{*}{$\begin{array}{c}\begin{array}{c}\text { Reducing } \\
\text { sugars } \\
(\%)\end{array} \\
11.55\end{array}$} & \multirow{2}{*}{$\begin{array}{c}\begin{array}{c}\text { Total } \\
\text { sugars } \\
(\%)\end{array} \\
15.31\end{array}$} & \multirow{2}{*}{$\begin{array}{c}\begin{array}{c}\text { Total } \\
\text { Polyphenols } \\
\text { (mg/100g) }\end{array} \\
15.91\end{array}$} & \multirow{2}{*}{$\begin{array}{c}\text { Anthocyanins } \\
\text { (mg/100g) }\end{array}$} \\
\hline$T_{1}$ & $\mathrm{CaCl}_{2} \mathbf{1 \%}$ & & & & & & & \\
\hline$T_{2}$ & CA 1\% & 6.80 & 8.21 & 0.73 & 11.43 & 15.14 & 16.60 & 57.18 \\
\hline $\mathbf{T}_{3}$ & KMS 1\% & 6.30 & 8.27 & 0.72 & 11.28 & 15.54 & 15.83 & 60.32 \\
\hline $\mathbf{T}_{4}$ & $\mathrm{NaCl} 2 \%$ & 6.46 & 8.25 & 0.77 & 10.63 & 14.02 & 15.64 & 40.10 \\
\hline $\mathbf{T}_{5}$ & $\begin{array}{l}\text { CA 1\% + } \\
\text { KMS 0.5\% }\end{array}$ & 5.80 & 8.61 & 0.71 & 12.64 & 16.59 & 17.21 & 62.08 \\
\hline $\mathbf{T}_{6}$ & $\begin{array}{l}\mathrm{CaCl}_{2} 1 \%+ \\
\mathrm{CA} 0.5 \%\end{array}$ & 6.80 & 8.22 & 0.74 & 11.97 & 15.22 & 15.68 & 40.65 \\
\hline $\mathbf{T}_{7}$ & $\begin{array}{l}\text { KMS 1\% + } \\
\mathrm{CaCl}_{2} 1 \%\end{array}$ & 5.60 & 8.69 & 0.66 & 12.84 & 16.63 & 17.00 & 61.70 \\
\hline$T_{8}$ & Control & 7.10 & 8.17 & 0.76 & 10.44 & 13.60 & 15.60 & 36.13 \\
\hline & S.E m \pm & 0.10 & 0.05 & 0.017 & 0.08 & 0.02 & 0.07 & 0.71 \\
\hline & .D. at $5 \%$ & 0.31 & 0.16 & 0.051 & 0.26 & 0.06 & 0.22 & 2.16 \\
\hline
\end{tabular}




\section{Total sugars}

There was a slight increase in total sugar per cent after dehydration (Table 3) which may be due to removal of moisture. The total sugar in all treatments, were found to be higher than the fresh pomace. The treatment $\mathrm{T}_{7}$ showed higher total sugar of 16.63 per cent which was on par with $\mathrm{T}_{5}$ recorded16.59 per cent of total sugars. The lowest sugar of 13.60 per cent was recorded in $\mathrm{T}_{8}$ (control).

The changes in total sugar percent may be related to two reactions. i.e., non-enzymatic browning which was found to be more in control samples and less in $\mathrm{KMS}+\mathrm{CaCl}_{2}$ treated sample. The results obtained in this study are similar to Ghavidel and Davoodi (2009) and Gallali et al., (2000).

\section{Total polyphenols}

After dehydration there was increase in polyphenol content in all the treatments (Table 3). Higher phenols of $17.21 \mathrm{mg} / 100 \mathrm{~g}$ were recorded in $T_{5}$ which followed by $T_{7}$ recorded of $17.00 \mathrm{mg} / 100 \mathrm{~g}$. The lowest phenol of $15.60 \mathrm{mg} / 100 \mathrm{~g}$ was recorded in $\mathrm{T}_{8}$ (control). The increase in the polyphenol content that takes place in dehydrated fruits is due to the formation of molecules with a lower molecular weight at moderately high temperatures, such as $60^{\circ} \mathrm{C}$ temperature applied during the pomace drying process.

Citric acid and KMS are added in order to prevent pomace from the enzymatic browning. Addition of these chemicals as antibrowning agents has a positive effect, since they improve the antioxidant capacity of dehydrated pomace significantly. Citric acid produces a $\mathrm{pH}$ reduction, thus decreasing the enzyme activity, whereas potassium metabisulphite is the most potent polyphenol oxidase inhibitor. The results of present investigation are in accordance with the findings of Quitral et al., (2013) in evaluation of antioxidant capacity and total polyphenol content in different apple varieties.

\section{Anthocyanins}

After dehydration there was decrease in anthocyanins content in all treatments (Table 3). Highest anthocyanin retention of 62.08 $\mathrm{mg} / 100 \mathrm{~g}$ was recorded in $\mathrm{T}_{5}$ followed by $\mathrm{T}_{7}$ recorded $61.70 \mathrm{mg} / 100 \mathrm{~g}$ and $\mathrm{T}_{3}$ (KMS $1 \%$ ) of $60.32 \mathrm{mg} / 100 \mathrm{~g}$ anthocyanins. The lowest value of $36.13 \mathrm{mg} / 100 \mathrm{~g}$ was recorded in $\mathrm{T}_{8}$ (control).

This difference was caused by the pre-treating with chemicals that leached out some anthocyanins. Anthocyanins leakage might happen due to dewaxing, which was caused by soaking during the pretreatment. This observation is comparable to the study by (Lohachoompol et al., 2004) who found that dewaxing weakened the berry cuticle and allowed the skin to rupture. This permitted some leakage from the exposed edges or undersurface of the torn skin to the pretreated solution that caused anthocyanins loss before the drying process. Similar, thermal processing destroyed some anthocyanins.

Using potassium metabisulfite (KMS) solution and combination of KMS with other chemical reagents resulted in better colour retention and was found to be very effective in the inhibition of both enzymatic and nonenzymatic browning. Especially, citric acid and potassium metabisulfite were used to reduce browning reaction in many types of fruit (Taylor and Bush, 1986). The results of present investigation are in accordance with the findings of Tassanaudom and Kengkhetkit. (2009) in dried longan.

It may be concluded from the present investigation that among the treatments, $\mathrm{T}_{7}$ (KMS $1 \%+\mathrm{CaCl}_{2} 1 \%$ ) recorded highest 
recovery per cent (26.32), rehydration ratio (1.57) and reconstituability ratio (0.41) with lowest dehydration ratio (3.79) followed by $\mathrm{T}_{5}(\mathrm{CA} 1 \%+\mathrm{KMS} 0.5 \%$ ) pre-treated pomace with recovery per cent (26.24), rehydration ratio (1.55) and reconstituability ratio $(0.40)$ with lowest dehydration ratio (3.81).

In quality aspects, $\mathrm{T}_{7}\left(\mathrm{KMS} 1 \%+\mathrm{CaCl}_{2} 1 \%\right)$ pre-treated pomace recorded highest TSS $\left(8.69{ }^{\circ} \mathrm{B}\right)$, reducing sugars $(12.84 \%)$, total sugars $(16.63 \%)$, minimum acidity $(0.66 \%)$ and preferred moisture $(5.60 \%)$ followed by $\mathrm{T}_{5}(\mathrm{CA} 1 \%+\mathrm{KMS} 0.5 \%)$ with $\mathrm{TSS}\left(8.61^{\circ} \mathrm{B}\right)$, reducing sugars $(12.64 \%)$, total sugars (16.59\%), minimum acidity $(0.71 \%)$ and preferred moisture $(5.8 \%)$. Whereas higher content of total polyphenols $(17.21 \mathrm{mg} / 100 \mathrm{~g})$ and anthocyanins $(62.08 \mathrm{mg} / 100 \mathrm{~g})$ was recorded in $\mathrm{T}_{5}$ (Citric acid $1 \%+\mathrm{KMS} 0.5 \%$ ) followed by $\mathrm{T}_{7}$ (KMS $1 \%+\mathrm{CaCl}_{2} 1 \%$ ) with total polyphenols $(17.00 \mathrm{mg} / 100 \mathrm{~g})$ and anthocyanins $(61.70 \mathrm{mg} / 100 \mathrm{~g})$ Though, the dehydrated pomace pretreated with Citric acid $1 \%+\mathrm{KMS} 0.5 \%\left(\mathrm{~T}_{5}\right)$ had highly retained total polyphenols and anthocyanins content, the two dehydrated pomace viz., grape pomace pretreated with $\mathrm{T}_{5}$ (Citric acid $1 \%+$ $\mathrm{KMS} 0.5 \%$ ), and $\mathrm{T}_{7}$ (KMS $1 \%+\mathrm{CaCl}_{2} 1 \%$ ) got best score in quality evaluation.

\section{Acknowledgement}

Authors are thankful to SKLTSHU, Hyderabad, for providing stipend and the necessary facilities to carry out this work.

\section{References}

Abrol G S, Vaidya D. and Sharma S. 2014. Effect of solar drying on physicochemical and antioxidant properties of mango, banana and papaya. National Academy Science Letters. 37(1):51-57.

Cantos E, Espin J C. and Tomas F A. 2002. Varietal differences among the polyphenol profiles of seven table grape cultivars studied by LC-DAD-MS-MS. Journal of Agriculture and Food Chemistry. 50 (20):5691- 5696.

Fontana A. R, Antoniolli A. and Bottini R. 2013. Grape pomace as a sustainable source of bioactive compounds: Extraction, characterization, and biotechnological applications of phenolics. Journal of Agricultural and Food Chemistry. 61(38): 8987-9003.

Gajanana T M, Sudha M, Saxena A K. and Dakshinamoorthy, V. (2010). Postharvest handling, marketing and assessment of losses in papaya. Acta Horticulture. 851:519-526.

Galleano M, Calabro V, Prince P D, Litterio M C, Piotrkowski B. and VazquezPrieto M A. 2012. Flavonoids and metabolic syndrome. Annals of the New York Academy of Sciences. 1259(1), 8794.

Gallali M Y, Abujnah Y S. and Bannani F K. 2000. Preservation of fruits and vegetables using solar drier a comparative study of natural and solar drying III. Chemical analysis and sensory evaluation data of the dried samples (grapes, figs, tomatoes and onions). Renewal Energy. 19(1-2):203212.

Ghavidel R A. and Davoodi M G. 2009. Studies on physiochemical properties of tomato powder as affected by different dehydration methods and pretreatments. International Scholarly and Scientific Research \& Innovation. 3(6): 331-339.

Lohachoompol, V, Srzednicki, G. and Craske, J. 2004. The change of total anthocyanins in blueberries and their antioxidant effect after drying and freezing. Journal of Biomedicine and Biotechnology. 5(1):248-252.

Mahajan, B C, Dhatt, A.S, Satish, K. and Manohar, L. 2009. Studies on cool storage of grapes for extended 
marketability. Journal of Food Science and Technology. 46(4):363-366.

Mozumder, N H M R, Rahman, M A, Kamal, M S, Mustafa, A K M. and Rahman, M S. 2012. Effects of pre-drying chemical treatments on quality of cabinet dried tomato powder. Journal Environmental Science \& Natural Resources, 5(1): 253-265.

National Horticulture Database, 2015-16. National Horticulture Board, Ministry of Agriculture, Government of India. http:nhb.gov.in/area-pro/database2015.

Patil, R, Mandar Khanvilkar, D N, Mokat, P, Relekar, P. and Pujari, K H. 2014. Effect of pre-treatments on physicochemical composition of dehydrated jackfruit chips during storage at ambient temperature. Life Sciences Leaflet. 54:27-35.

Quitral V, Sepulveda M. and Schwartz M. 2013. Antioxidant capacity and total polyphenol content in different apple varieties cultivated in chile. Rev. Iber. Tecnología Postcosecha. 14(1):31-39.

Ranganna S. 1998. Handbook of Analysis and
Quality Control for Fruits and vegetable Products. Tata McGraw Hill Publishing Company Limited, New Delhi.

Singleton, V L, Orthofer, R. and Lamuela Raventos, R M. 1999. Analysis of total phenols and other oxidation substrates and antioxidants by means of Folin- Ciocalteu reagent. Methods in Enzymology. 299:152-178.

Srivastava, R P. and Sanjeevkumar, N. 1998. Fruit and Vegetable Preservation, principles and practices - 2nd Edn., International Book Distributing Co. (Publishing Division), U. P., India.

Tassanaudom U. and Kengkhetkit N. 2009. The colour attribute improvement of dried longans. NU Science Journal. 6(S1): $114-122$.

Taylor, S L. and Bush, R K. 1986. Sulfites as food ingredients. Journal of Food Technology, 40(60):47-52.

Xia E Q, Deng G F, Guo, Y J and Li H B. 2010. Biological activities of polyphenols from grapes. International Journal of Molecular Sciences. 11: 622-646.

\section{How to cite this article:}

Mamatha, P., K. Vanajalatha, Veena Joshi and Narender Reddy, S. 2017. Effect of PreTreatments on Quality Attributes of Solar Dehydrated Grape Pomace. Int.J.Curr.Microbiol.App.Sci. 6(6): 3013-3021. doi: https://doi.org/10.20546/ijcmas.2017.606.358 